\title{
RURAL TOURISM IN THE FUNCTION OF LIFE QUALITY IMPROVEMENT OF RURAL POPULATION ON GOČ MOUNTAIN
}

\author{
Milena Podovac ${ }^{1}$, Nataša Đorđević ${ }^{2}$, Snežana Milićević ${ }^{3}$ \\ *Corresponding authorE-mail:milena.podovac@kg.ac.rs
}

A R T I C L E I N F O
Review Article
Received: 28 November 2018
Accepted: 28 December 2018
doi:10.5937/ekoPolj1901205P
UDC
$338.48-44(1-22): 330.59(497.11$ Goč)

Keywords:

rural tourism, local community, mountain Goč

JEL: L83, Z32

\section{A B S T R A C T}

The aim of the paper is to determine the possibilities for improving rural tourism on the mountain Goč, as well as how this type of tourism can affect the quality of life of the rural population in this area. The methods used in this paper include fieldwork and cabinet research. The survey was carried out on random sample by sending a questionnaire via e-mail. The research involved 150 respondents. Mountain Goč has resources for the development of rural tourism. It is necessary to improve the quality of accommodation capacities and the quality of additional content of rural tourism. The development of rural tourism on the mountain Goč can have favorable impacts on the quality of life of the rural population.

(C) 2019 EA. All rights reserved.

\section{Introduction}

Modern way of human living is characterized by a fast pace, stress, alienation, lack of time for themselves and their families, unhealthy and fast food, specific diseases and unproductiveness at work. Precisely because of this, the motives for coming to the village such as: peace, clean environment, interaction with new people (local villagers), healthy food, slow food (slow eating, enjoying the food), slower pace of life and leisure, are responsible for the development of and survival of rural tourism as a tourism oriented towards an individual customer and his needs (Đenadić et al., 2016).

Rural tourism today is not the only means of revitalization of the abandoned rural areas, but it certainly is one of the major factors of the development of rural areas, which ensures their future sustainability through preservation, and opening of new job opportunities,

1 Milena Podovac, teaching assistant, University of Kragujevac, Faculty of Hotel Management and Tourism in Vrnjačka Banja, Vojvođanska 5A, 36210 Vrnjačka Banja, 036/5150024, milena.podovac@kg.ac.rs, (https://orcid.org/0000-0002-0709-2927)

2 Nataša Đorđević, teaching assistant, University of Kragujevac, Faculty of Hotel Management and Tourism in Vrnjačka Banja, Vojvođanska 5A, 36210 Vrnjačka Banja, 036/5150024, natasa.djordjevic@kg.ac.rs ORCID ID (https://orcid.org/0000-0002-3630-6867)

3 Snežana Milićević, associate professor, University of Kragujevac, Faculty of Hotel Management and Tourism in Vrnjačka Banja, Vojvođanska 5A, 36210 Vrnjačka Banja, 036/5150024, snezana. milicevic@kg.ac.rs, ORCID ID (https://orcid.org/0000-0002-1972-9585) 
increasing the diversity of occupations, preservation of landscape and nature as well as support to the rural crafts and tourist attractions (Maksimović et al., 2015).

The subject of this paper is the analysis of the possibilities for rural tourism development as a factor of improving life quality of rural population on the Goč mountain. In addition to the fact that it is situated in the vicinity of one of the most visited tourist destinations in Serbia, Vrnjačka Banja, the basis for tourism development on Goč mountain are the diversity of flora and fauna, climatic predispositions and hydrographic potential. Basic research questions are whether Goč mountain has the potentials for rural tourism development and in what manner the tourism development affects the rural population in this area. Main hypothesis of this paper is: Rural tourism can contribute to the improvement of rural population's life quality on Goč mountain.

\section{Literature review}

At the beginning of the XXI century, in accordance with specific requirements of the users of tourist services, there are new forms of tourism developed, within which rural tourism occupies a significant place. Rural tourism is a form of tourism which includes all tourist activities which can take place in rural regions and which can be included in tourist offer of those regions (Njegovan et al., 2015). Rural tourism should be based in those areas which are rural in all aspects (Lane, 1994). The term ,rural area" means the area whose main feature is primarily the use of land for agriculture and forestry (Prentović et al., 2012). Rural areas have a special position as areas of excellence, as well as ecological oases which are the foundations of traditional culture and ethno-cultural heritage (Štetić, 2012).

The elements of rural regions, which are included in tourist product are based on natural values, as well as anthropogenic resources and infrastructure in general (Milićević, Podovac, 2012). According to Garrod (2006), constituent elements of countryside capital are: Landscape, Wildlife (both fauna and flora), Biodiversity, Geology and soils, Air and air quality, Hedgerows and field boundaries, Agricultural buildings, Rural settlements, Historical features, Streams, rivers, ponds and lakes, Water and water quality, Woods, forests and plantations, Distinctive local customs, languages, costumes, foods, crafts, festivals, traditions, ways of life. Rural tourism is complex and is divided to several segments: natural, rural environment (rivers, lakes, forest), rural cultural and spiritual things (architecture, churches and monasteries), ethno tourism (traditional food, music, customs) and rural activities such as horseback riding, fishing, hunting (Molera, Albaladejo, 2007).

The authors represent different views when it comes to activities that make rural tourism product (Milićević et al., 2015). Rural tourism encompasses a variety of tourists activities including direct participation in agricultural activities (e.g. harvesting berries), indirect enjoyment of farm activities (e.g. enjoying meals on site), recreational activities (e.g. ride a bicycle) and activities in which the farm premises only serves as the landscape (e.g. wedding in a vineyard), as well as a variety of on-farm accommodations services and food services (Barbieri, 2013; Phillip et al., 2010; McGehee, Kim, 2004). 
Most studies stress the value of various economic, sociocultural and environmental benefits of rural tourism that, although primarily concern the farm household, also extend to surrounding communities (Barbieri, 2013). Rural tourism is a significant factor of recovery and development of rural areas and a significant generator of the income for rural households (Milićević et al., 2015), i.e. a significant factor of revitalization and diversification of rural economy (Saarinen, Lenao, 2014). Economic effects of rural tourism development in rural areas primarily reflect themselves through the possibility of employment of rural population, and consequently the growth of their life standard (Mitchell, Hall, 2005). Rural tourism provides additional income to people in rural areas through the placement of agricultural products in the market in their own yards, as well as placement of the handicraft products. Rural tourism provides valorization of women's work in rural households, as well as employment of labourinactive categories of people (Njegovan et al., 2015). Furthermore, revitalized local economies foster youth retention in rural communities who work in either agriculture or other local businesses (Sharpley, 2002).

Tourism contributes to meeting different cultures, lifestyles, and consequently better understanding of different people. The socio-cultural effects of rural tourism are reflected through interactions among urban dwellers, rural villagers and the rural areas, but above all through the revitalization of local crafts, customs and cultural identities (Košić et al., 2015), ie preservation of local cultural heritage. An increased interest in heritage can be satisfied through rural tourism as rural areas are often the repositories of remnant heritage (Irshad, 2010). Traditional festivals, events and folklore can also be an important part of tourist offer of rural areas (Grossman, 2013). Ecological effects of rural tourism reflect themselves in improvement of the quality of rural environment, as well as protection of the nature beauty and eco-system (Liu, 2002). Rural areas are perceived as healthier, offering fresher air, cleaner water and the opportunity for outdoor recreation. Rural areas offer fresh foods (Irshad, 2010).

\section{Rural tourism and local community - Examples of good practice}

In practice, there are numerous examples of rural areas, where material position of population is improved by the development of rural tourism. In the Cluj County in Romania, to help development of the rural tourism, there is cooperation with local producers (suppliers). These local producers provide the touristic units with meat and dairy products, forest fruits and mushrooms, lavender, strawberry, honey, wine, oil, traditional fabrics (cloths - hats, fur coats; carpets; wood carvings) or equestrian services. In most cases, tourists are allowed to visit households of local producers, having the opportunity to see traditional production methods and to find out the story which lies behind the technique. Also, in this area there is a cooperation between similar units. For example, in the village Măriel accommodation unit is cooperating with another guesthouse in organizing events, sharing tourists and marketing activities. In the village Sâncraiu over 40 small accommodation units are organized in a rural tourism network. The whole activity is coordinated by a travel agent, who creates the 
tourist packages, brings the tourists, organizes the activities and promote the village as a tourist destination, sharing all the costs with the network members. These 40 small touristic units in the village Sâncraiu compete on the global touristic market by co-operating locally. They attend national and international tourism fairs, promoting Sâncraiu as a tourism destination and inviting tourists to spend their holidays in one of the most natural traditional regions in Europe (Toader et al., 2013).

Acording to the Jaszczak and Žukovskis (2010) research about tourism business of European rural areas, the income from tourism in agritourism farm in Finland and Poland is additional for the family running the farm, but it is often higher than the income from husbandry. As they noticed rural tourism and agritourism in countries they analised - Finland, Italy and Poland, are related to the development of the whole farm offering the services as well as with the economical and social development of rural areas. The livelihood of country people and stopping their migration to cities have become important factors determining this development. Activating the society, cultivating traditions and customs as well as environmental protection have been decisive in the success of the planned touristic enterprises. Also the development of touristic products for the whole region has been of great importance.

The idea of developing rural tourism can encourage local people to innovate. Good example for this is ethno village "Latkovac" in Serbia. A hamlet in which there is a cultural-tourist center "Latkovac" situated, which is over 200 years old. At this place, two centuries ago, there was a center of the parish at the time, while in the oldest house in the village, there was a court house. The owners of the facility in this hamlet have decided to direct the function of these old objects towards tourism. The offer of this ethno village is diverse and innovative and based on a great number of activities (concerts, festivals, shows, interactive workshops), and tourists are offered a stay in nature with a possibility to walk along marked hiking trails, sports and recreation activities, hunting, picking forest fruits and herbs; there is a possibility of learning some of the foreign languages, taking part in art workshops (painting, pottery, caligraphy, etc), or educational camps on the subject of ecology and ethnology, performance of daily tasks in the village and the like (Simić, 2015). In the research about forecasts of the rural tourism development in Kosjerić and Gornji Milanovac municipalities the autors states that the economic effects of rural tourism are really high, because the hosts realize revenue from the sale of local products, as well as other service providers (the multiplicative effect) (Pavlović, Đorđević, 2013).

\section{Resources of the mountain Goč in the function of rural tourism development}

Although the structure of resources is compatible to the concept of rural tourism development, this form of tourism still hasn't reached the appropriate level so that the region of Goč mountain could become a rural destination. Goč mountain is geographically positioned south from West Morava river in the vicinity of Vrnjačka Banja at the elevation ranging from $300 \mathrm{~m}$ to $1.154 \mathrm{~m}$ (available at: www.vrnjackabanja.co.rs). It highest peak is Krnja jela, which is at elevation of 1.127 m (Kostić, Petrović, 2013). In addition to being 
in the vicinity of the leading spa destination in Serbia, comparative advantage of Goč mountain is reflected in its natural predispositions. Ecologically preserved environment, which is specific for extreme woodiness, natural landscapes and diverse flora and fauna, are the characteristics that classify Goč mountain as one of the destinations that are still insufficiently explored and involved in tourist flows. Therefore, the existing resources are a significant precondition of a rural tourism development on Goč mountain in order to achieve a more intensive tourism inclusion of rural population.

Natural characteristics of Goč mountain have, to a greater extent, determined its further development in order to encourage agricultural production, but with an insufficient inclusion of tourism as an activity which can contribute to a better material position of the population. The region of Goč mountain is characterized by moderate continental climate. Due to the existence of a great number of woody and hilly areas, there are no sudden alterations of temperature (Sustainable Tourism Development Program on the Mountain Goč, 2018). The diversity of flora and fauna is reflected in the existence of 650 plant species, among which over 200 are medicinal and aromatic herbs. For the development of rural tourism, it is significant that Goč mountain region mainly consists of woods, grasslands, meadows as well as plowed lands, orchards and gardens, which can be used for growing a large number of agricultural products. Hydrographic potential of Goč mountain is based on streams and streamlets, which flow towards West Morava on the north and Rasina on the south. Hydrogeographic network also includes artificial accumulation lake Selište, which includes the space of about 8 ha (Milićević, Đorđević, 2015). Of all the other hydrographic resources, the significant are Vrnjačka river, Novoselska river, Zagrža as the left tributary of Rasina with the basin of $23 \mathrm{~km}^{2}$ etc. (Sustainable Tourism Development Program on the Mountain Goč, 2018).

In the forest area of Goč mountain there are different game species, which makes hunting one of the potentially significant activities for the tourists (Podovac, Milićević, 2013). In the region of Goč mountain there are the following game species: deer, wild boar, marten, rabbit, wolf, fox, etc. In addition to a great number of game species, animal world includes 317 insect types, among which 57 species are rare and endangered species at national and international level. There were recorded 129 types of birds with the presence of many species which are of international significance. Among 27 types of mammals, the highest value has the otter, which is protected by law as natural rarity (Sustainable Tourism Development Program on the Mountain Goč, 2018).

One of the aggravating circumstances in rural tourism development is certainly the unfavourable demographic structure of population. According to the census from 2011, on Goč mountain there exists 32 households, among which the greatest number of households include one or two members (available at: http://popis2011.stat.rs/). The villages Goč and Stanišinci are particularly attractive for the development of rural tourism and a small number of people live in them even though there exists basic infrastructure required for functioning of rural environment (Milićević, Đorđević, 2015). 
Material base for development of rural tourism of Goč mountain is not sufficiently developed. The existing offer of accommodation on Goč mountain is extremely modest. Accommodation offer of Goč mountain includes guest houses („Kaćunak“, „Goč“, „Gočka kuća“), mountain houses (,Goč“, „Pecić“", „Radulovićc), apartments („Horizont", „Velja“, Đurovski“, „Nikola i Barbara“) and villas ("Slavica“). On Goč mountain, there is also a children's resort „Dobre vode“, which is next to ski slope. Next to children's resort, there also is a private accommodation in a form of two ethnic wooden cottages (,Goč“, ,Metikoši“) (available at: https://www.goc.rs/smestaj/).

Crucial tourist products of Goč mountain are: winter tourism, sports and recreation, excursion, hunting and fishing (Podovac, Milićević, 2013). Development of winter tourism is based on the existence of a cable car and a ski slope, at the distance of $10 \mathrm{~km}$ from Vrnjačka Banja. The foothill of ski slope is at the elevation of $1.123 \mathrm{~m}$. Sports and recreation tourism is developed due to the existence of the playing grounds for different sports activities. Goč mountain disposes with the potentials for a more intensive development of hunting and fishing. Two settled hunting grounds are the carriers of hunting tourism development. Hunting ground ,Vrnjačka reka“ occupies the surface of 13.775 ha from Goč to Morava with the reservation surface of 2.900 ha. In its territory, which is $95 \%$ in private ownership, there are different game species such as wild boar, rabbit, squirrel, etc. Hunting ground „Beli izvor" occupies the surface of 8.768 ha, where the surface of 8.713 ha is settled as a hunting surface, while the rest territory is arranged as a part for intensive hunting management (fenced surface of 615 ha, where deer and wild boar are bred). In the hunting ground you can find: roe deer, rabbit, pheasant, wolf, fox, deer, wild boar, etc. Development of sport fishing is present on West Morava and Podunavacke bare, where in addition to sport competitions, there are also the conditions for recreational fishing (Sustainable Development Strategy of the Municipality of Vrnjačka Banja, 2013). Excursions are also present on Goč mountain and they are manifested in a form of tourist activities, which do not impair its ecological integrity (hiking, active holiday, picking of herbs and mushrooms and other forest fruits, flowers, etc.)

\section{Research methodology and hypothesis}

The subject of the study in this paper is rural tourism as a factor oflife quality improvement of rural population on Goč mountain. The study of the respondents' attitudes regarding the significance of rural tourism for the rural population life quality improvement on Goč mountain was carried out in the period from 14.10.2018. to 02.11.2018. by sending a questionnaire to e-mail addresses of respondents, who are mainly from the territory of Vrnjačka Banja and its direct vicinity. The study was proceeded by the preparation of a questionnaire, which consists of the 10 questions of opened and closed type. Questionnaire is divided in two parts. The first type of questionnaire consists of 5 questions, which refer to socio-demographic characteristics of respondents. In the second part of the questionnaire, which also consists of 5 questions, respondents have given the answers to questions on the quality of the existing offer of rural tourism on Goč mountain and manners to improve it, as well as level of including rural population 
in rural tourism development and manners for its more active engagement in order to provide a better material position. The questionnaire was distributed to 500 addresses, where 220 answers were gathered. In further study, there were analyzed exclusively the answers of 150 respondents who visited Goč mountain. In this manner, it was ensured that the respondents were familiar with the existing state of offer of rural tourism on Goč mountain, as well as the life quality of rural population. The main goal of the implemented study refers to examining the possibilities for the improvement of rural tourism in order to provide better material position through its development, as well as life quality of rural population on Goč mountain.

In the paper, descriptive statistical analysis and Mann-Whiney's U-test are used. Main hypothesis, which says: Rural tourism can contribute to rural population's life quality improvement, is operationalized into the following special hypothesis:

H1: Goč mountain possesses the potentials for rural tourism development.

$\mathrm{H} 2$ : There is a statistically significant difference between the attitudes of respondents, who live in the territory of Vrnjačka Banja and out of it in the aspect of the existence of potentials for development of rural tourism on Goč mountain.

H3: There is a statistically clear difference between the attitudes of respondents who live on the territory of Vrnjačka Banja and out of it regarding the involvement level of rural population on Goč mountain in rural tourism development.

H4: Rural population is not sufficiently included in development of rural tourism on Goč mountain.

H5: Respondents agree in the attitude that rural tourism development can contribute to the improvement of rural population life quality on Goč mountain.

\section{Results and discussion}

The study included 150 respondents, where 113 were females $(75,3 \%)$ and 37 males $(24,7 \%)$. Within the question regarding the age, there were 5 age groups defined. The highest participation in the sample have the respondents who belong to the age group from 20 to 25 years, more precisely 64 of them $(42,7 \%)$, as well as respondents aged 26-35, i.e. 47 respondents $(31,3 \%)$.

According to education level, the majority are those respondents with $\mathrm{MA}$ or $\mathrm{PhD}$ degree, more precisely 51 respondent (34\%). In addition, a significant participation in the sample also take the respondents with bachelor degree, i.e. 50 respondents $(33,3 \%$.) When it comes to the professional status, 87 respondents (58\%) are employed, while 49 respondents $(32,7 \%)$ have the status of the student. The greatest number of respondents, i.e. $96(64 \%)$ live outside the territory of Vrnjačka Banja, where the majority were the respondents from towns which are situated in the vicinity (Kraljevo, Trstenik, Kruševac, Kragujevac etc.). The question Does Goč mountain possess the potential for rural tourism development?, was affirmatively answered by 148 respondents (98,7\%) (Table 1.). 
Table 1. Socio-demographic characteristics of respondents

\begin{tabular}{|c|c|c|c|c|c|}
\hline & & Frequency & $\begin{array}{c}\text { Percentage } \\
(\%)\end{array}$ & Mean & $\begin{array}{l}\text { Standard } \\
\text { deviation }\end{array}$ \\
\hline \multirow{2}{*}{ Gender } & Male & 37 & 24,7 & \multirow{2}{*}{1,75} & \multirow{2}{*}{,433 } \\
\hline & Female & 113 & 75,3 & & \\
\hline \multirow{5}{*}{ Age } & $20-25$ & 64 & 42,7 & \multirow{5}{*}{1,95} & \multirow{5}{*}{1,064} \\
\hline & $26-35$ & 47 & 31,3 & & \\
\hline & $36-45$ & 27 & 18 & & \\
\hline & $46-55$ & 6 & 4 & & \\
\hline & More than 55 years & 6 & 4 & & \\
\hline \multirow{4}{*}{ Level of education } & High school & 43 & 28,7 & \multirow{4}{*}{2,73} & \multirow{4}{*}{1,209} \\
\hline & College & 6 & 4 & & \\
\hline & University degree & 50 & 33,3 & & \\
\hline & $\begin{array}{c}\text { Master/Magistar/ } \\
\mathrm{PhD} \\
\end{array}$ & 51 & 34 & & \\
\hline \multirow{4}{*}{ Professional status } & Unemployed & 13 & 8,7 & \multirow{4}{*}{2,25} & \multirow{4}{*}{,615 } \\
\hline & Employed & 87 & 58 & & \\
\hline & Student & 49 & 32,7 & & \\
\hline & Retired & 1 & 0,7 & & \\
\hline \multirow{2}{*}{$\begin{array}{l}\text { Place of permanent } \\
\text { residence }\end{array}$} & $\begin{array}{l}\text { In the territory of } \\
\text { Vrnjačka Banja }\end{array}$ & 54 & 36 & \multirow{2}{*}{1,64} & \multirow{2}{*}{,482 } \\
\hline & $\begin{array}{c}\text { Out of the territory of } \\
\text { Vrnjačka Banja }\end{array}$ & 96 & 64 & & \\
\hline \multirow{2}{*}{$\begin{array}{c}\text { Does mountain Goč } \\
\text { have the potential } \\
\text { to develop rural } \\
\text { tourism? }\end{array}$} & Yes & 148 & 98,7 & \multirow{2}{*}{1,01} & \multirow{2}{*}{, 115} \\
\hline & No & 2 & 1,3 & & \\
\hline
\end{tabular}

Source: Authors, based on research

To the question which required the evaluation of the existing state of some elements of the offer of rural tourism of Goč mountain, the respondents gave grades on Likert scale from 1-Very bad to 6-Excellent. Based on the data, which are presented in Table 2, it was obvious that average evaluations of offer elements of rural tourism on Goč mountain move within the range from 2,48 to 3,83. The highest grades have the following elements: Hospitality and kindness from the part of local population $(\mathrm{AS}=3,83)$, as well as Attractiveness of natural attractions $(\mathrm{AS}=3,63)$. On the other hand, the poorest grades have the following elements of rural tourism offer: Presence, number and quality of accommodation offer $(\mathrm{AS}=2,48)$ and Presence and quality of tourist signalization ( $\mathrm{AS}=2,60)$ (Table 2.). 
Table 2. Respondents' answers to the question of the quality of rural tourism supply on mountain Goč

\begin{tabular}{|c|c|c|c|c|c|c|c|}
\hline Answers & $\begin{array}{c}\text { Very } \\
\text { poor }\end{array}$ & Poor & Average & $\begin{array}{c}\text { Very } \\
\text { good }\end{array}$ & Excelent & AS & SD \\
\hline $\begin{array}{c}\text { Attractiveness and soundness } \\
\text { of rural area }\end{array}$ & 3,3 & 14 & 38,7 & 33,3 & 10,7 & 3,34 &, 961 \\
\hline $\begin{array}{c}\text { Attractiveness of natural } \\
\text { attractions }\end{array}$ & 2,7 & 7,3 & 36,7 & 31,3 & 22 & 3,63 &, 994 \\
\hline $\begin{array}{c}\text { Soundness of village } \\
\text { architecture }\end{array}$ & 4 & 21,3 & 43,3 & 22 & 9,3 & 3,11 &, 980 \\
\hline $\begin{array}{c}\text { Quality and diversity of } \\
\text { gastronomic specialties }\end{array}$ & 2,7 & 22,7 & 37,3 & 26,7 & 10,7 & 3,20 &, 997 \\
\hline $\begin{array}{c}\text { Presence and diversity } \\
\text { of cultural and historical } \\
\text { localities }\end{array}$ & 5,3 & 19,3 & 38,7 & 26,7 & 10 & 3,17 & 1,026 \\
\hline $\begin{array}{c}\text { Presence, number and quality } \\
\text { of accommodation offer }\end{array}$ & 9,3 & 47,3 & 31,3 & 10 & 2 & 2,48 &, 873 \\
\hline $\begin{array}{c}\text { Presence, number and quality } \\
\text { of offer in restaurants }\end{array}$ & 10 & 37,3 & 34 & 12,7 & 6 & 2,67 & 1,020 \\
\hline $\begin{array}{c}\text { Quality and development of } \\
\text { communal infrastructure }\end{array}$ & 10 & 30,7 & 50,7 & 9,3 & 3,3 & 2,73 &, 841 \\
\hline $\begin{array}{c}\text { Quality and development of } \\
\text { transport infrastructure }\end{array}$ & 2,7 & 28 & 44,7 & 20 & 4,7 & 2,96 &, 881 \\
\hline $\begin{array}{c}\text { Existing sports and } \\
\text { recreational content }\end{array}$ & 10,7 & 35,3 & 39,3 & 12 & 2,7 & 2,61 &, 926 \\
\hline $\begin{array}{c}\text { Presence and quality of } \\
\text { tourist signalization }\end{array}$ & 9,3 & 38,7 & 38 & 10,7 & 3,3 & 2,60 &, 920 \\
\hline $\begin{array}{c}\text { Arrangement and cleanness } \\
\text { of Goč mountain }\end{array}$ & 3,3 & 12,7 & 38,7 & 33,3 & 12 & 3,38 &, 967 \\
\hline $\begin{array}{c}\text { Hospitality and kindness } \\
\text { from the part of local } \\
\text { population }\end{array}$ & 2 & 4,7 & 30,7 & 34,7 & 28 & 3,83 &, 963 \\
\hline
\end{tabular}

Source: Authors, based on research

Respondents were asked How can the rural tourism offer of Goč mountain be improved?, and there were 10 questions offered, as well as the possibilities for the respondents to choose only one answer. The greatest number of respondents believe that the rural tourism offer of mountain Goč can be improved through Improvement of sportsrecreational and entertainment content for tourists - 58 respondents $(38,7 \%)$ as well as through Integration of the offer of Goč mountain in tourist offer of Vrnjačka Banja-22 respondents (14,7\%). In addition, respondents had the possibility to add another answer to this question, in addition to the offered. Under the option Other, 3 respondents have mentioned that they believe that answers offered cannot be significant for the offer improvement of Goč mountain, as well as the introduction of new tourist attractions. The attitudes of respondents are in agreement also when it comes to the fact that offer 
can be improved with a more active support of local self-government, education of local population on the significance of tourism as one of the leading economic activities today, etc. Other answers are shown in Table 3.

Table 3. Respondents' answers to the question about improving rural tourism offer on mountain Goč

\begin{tabular}{|c|c|c|c|c|}
\hline Answers & Frequency & Percent & $\begin{array}{c}\text { Valid } \\
\text { percent }\end{array}$ & $\begin{array}{c}\text { Cumulative } \\
\text { percent }\end{array}$ \\
\hline $\begin{array}{c}\text { Improvement of sports-recreational } \\
\text { and entertainment content for tourists }\end{array}$ & 58 & 38,7 & 38,7 & 38,7 \\
\hline $\begin{array}{c}\text { Raising the awareness and education } \\
\text { of local population on the tourism } \\
\text { significance for development of rural } \\
\text { area of Goč mountain }\end{array}$ & 15 & 10 & 10 & 48,7 \\
\hline $\begin{array}{c}\text { Financial and institutional support of } \\
\text { local government in order to strengthen } \\
\text { agriculture and tourism }\end{array}$ & 16 & 10,7 & 10,7 & 59,3 \\
\hline $\begin{array}{c}\text { Development of rural tourism on the } \\
\text { principles of sustainable development }\end{array}$ & 14 & 9,3 & 9,3 & 68,7 \\
\hline $\begin{array}{c}\text { Integration of the offer of Goč } \\
\text { mountain in tourist offer of Vrnjačka } \\
\text { Banja }\end{array}$ & 22 & 14,7 & 14,7 & 83,3 \\
\hline $\begin{array}{c}\text { Greater share of local agricultural } \\
\text { products in the preparation of } \\
\text { gastronomic specialities for tourists }\end{array}$ & 1 & 0,7 & 0,7 & 84 \\
\hline $\begin{array}{c}\text { Improvement of the quality of existing } \\
\text { and construction of new acomodation } \\
\text { capacities }\end{array}$ & 10 & 6,7 & 6,7 & 90,7 \\
\hline $\begin{array}{c}\text { Inclusion of local population in } \\
\text { providing accomodation through } \\
\text { engagement of their households }\end{array}$ & 7 & 4,7 & 4,7 & 95,3 \\
\hline $\begin{array}{c}\text { Hunting and fishing as additional } \\
\text { activities for tourists }\end{array}$ & 3 & 2,0 & 2 & 99,3 \\
\hline Other & 1 & $\mathbf{1 0 0}$ & $\mathbf{1 0 0}$ & 100 \\
\hline I don't know & 30 & 2 & \\
\hline Total & 7 & 16,7 & \\
\hline
\end{tabular}

Source: Authors, based on research

As for the question To what extent is the local population included in rural tourism development on Goč mountain?, the majority of respondents, i.e. 109 of them (72,7\%) believe that local population is not sufficiently included in development of this form of tourism on Goč mountain. On the other hand, 12 respondents $(8, \%)$ believe that they are not included, while 24 of them (6\%) don't know the answer to this question. Only 5 respondents $(3,3 \%)$ believe that they are included in development of rural tourism on Goč mountain.

Having in mind that respondents have expressed their opinion regarding the level of involvement of rural population, they were also asked about the manners in which rural population of Goč mountain can be included in rural tourism development. When it 
comes to manners for the inclusion of local population in rural tourism development on Goč mountain, respondents were offered 8 answers with the possibility to provide the answers themselves, the answer which is not among the offered ones and they believe that it can contribute to the inclusion of local population in development of rural tourism. The greatest number of respondents, i.e. 33 respondents each $(22 \%$ in case of both answers), have chosen the following answers: Production and sale of agricultural products to tourists and Providing the accommodation in private households. In addition, even 32 respondents $(21,3 \%)$ believe that the offer of rural tourism on Goč mountain could be improved by the Organization of attractive manifestations (gastronomic manifestations, country parties, folklores) (Table 4.). Under the option Other, 3 respondents have mentioned that most of the answers offered can enable the inclusion of local population in development of rural tourism on Goč mountain.

Table 4. Respondents' answers to questions about including the local population in the development of rural tourism on the mountain Goč

\begin{tabular}{|c|c|c|c|c|}
\hline Answers & Frequency & Percent & $\begin{array}{c}\text { Valid } \\
\text { percent }\end{array}$ & $\begin{array}{c}\text { Cumulative } \\
\text { percent }\end{array}$ \\
\hline $\begin{array}{c}\text { Production and sale of agricultural } \\
\text { products to tourists }\end{array}$ & 33 & 22 & 22 & 22 \\
\hline $\begin{array}{c}\text { Providing agricultural products to } \\
\text { catering facilities }\end{array}$ & 9 & 6 & 6 & 28 \\
\hline $\begin{array}{c}\text { Providing accommodation in private } \\
\text { households }\end{array}$ & 33 & 22 & 22 & 50 \\
\hline $\begin{array}{c}\text { Picking mushrooms, herbs and forest } \\
\text { fruits with a tourist guide }\end{array}$ & 16 & 10,7 & 10,7 & 60,7 \\
\hline $\begin{array}{c}\text { An active contact with tourists in a form } \\
\text { of performing agricultural works }\end{array}$ & 5 & 3,3 & 3,3 & 64 \\
\hline $\begin{array}{c}\text { Organization of attractive manifestations } \\
\text { gastronomic manifestations, country } \\
\text { parties, folklore) }\end{array}$ & 32 & 21,3 & 21,3 & 85,3 \\
\hline Learning about the old crafts & 4 & 2,7 & 2,7 & 88 \\
\hline Opening an ethno restaurant & 15 & 10 & 10 & 98 \\
\hline Other & 3 & 2 & 2 & 100 \\
\hline Total & $\mathbf{1 5 0}$ & $\mathbf{1 0 0}$ & $\mathbf{1 0 0}$ & \\
\hline
\end{tabular}

Source: Authors, based on research

\section{Testing of the hypotheses}

In this paper, there is a main hypothesis set, which says: Rural tourism can contribute to the improvement of rural population's life quality on Goč mountain. The exactness of this hypothesis was verified by the application of appropriate statistical analysis: descriptive statistical analysis and Mann-Whiney's U-test. A special hypothesis H1, which says: Goč mountain has the potentials for rural tourism development, is considered confirmed having in mind that 148 respondents $(98,7 \%)$ have said that Goč mountain owns the potentials for rural tourism development. 
In order to choose an appropriate statistical test for the verification of special hypotheses, there was performed the evaluation of the normality of allocation due to the fact that majority of statistical tests are based on the assumption of the normality of the dependent variable (Pallant, 2009). Based on the results of Kolmogorov-Smirnov test (Sig. .000), the assumption on normality of allocation is rejected and for that reason, instead of t-test, which is a parametric test, Mann-Whiney's U-test is used (Table 5.).

Table 5. Result of Mann-Whineyjev U-test

\begin{tabular}{|c|c|}
\hline & $\begin{array}{c}\text { Does mountain Goč have the potential to } \\
\text { develop rural tourism? }\end{array}$ \\
\hline Mann-Whitney U & 2538,000 \\
\hline Wilcoxon W & 4023,000 \\
\hline Z & $-1,064$ \\
\hline Asymp. Sig. (2-tailed) &, 287 \\
\hline
\end{tabular}

Source: Authors, based on research

A special hypothesis H2, which says: There is a statistically significant difference between the attitudes of respondents who live on the territory of Vrnjacka Banja and out of it on the existence of the potentials for development of rural tourism on Goc mountain, was tested by Mann-Whiney's U-test. Based on the Asymp. Sig. (,287), which is higher than 0,05 , we can conclude that special hypothesis $\mathrm{H} 2$ is not confirmed. Based on the results of the test applied, it was determined that there is no statistically significant difference between the attitudes of respondents who live on the territory of Vrnjačka Banja and out of it regarding the potentials for the development of rural tourism on Goč mountain.

In addition, special hypothesis H3, which says: There is a statistically clear difference among the attitudes of respondents who live on the territory of Vrnjacka Banja and out of it regarding the inclusion level of rural population on Goc mountain in rural tourism development, was also tested through Mann-Whiney's U-test. Having in mind that the value on Asymp. Sig (,002) is less than,005, this hypothesis can be taken as true. It was determined that there is a statistically significant difference between the attitudes of respondents on the inclusion level of rural population on Goč mountain in rural tourism development.

Table 6. Result of Mann-Whineyjev U-test

\begin{tabular}{|c|c|}
\hline & $\begin{array}{c}\text { To what extent is the local population } \\
\text { involved in the development of rural tourism } \\
\text { on the mountain Goč? }\end{array}$ \\
\hline Mann-Whitney U & 1977,500 \\
\hline Wilcoxon W & 3462,500 \\
\hline Z & $-3,076$ \\
\hline Asymp. Sig. (2-tailed) &, 002 \\
\hline
\end{tabular}

Source: Authors, based on research 
Special hypothesis H4 which says: Rural population is not sufficiently included in rural tourism development on Goč mountain, is confirmed by respondents answers, 109 of which $(72,7 \%)$ from the total number have said that rural population is not sufficiently included in development of this form of tourism. Based on the answers of respondents to the question regarding the manners of improving the inclusion of rural population in rural tourism development of Goč mountain, the special hypothesis H5 is accepted, which says: Respondents agree that rural tourism development can contribute to the improvement of rural population's life quality on Goč mountain, as true. Respondents have said that there are different manners for the inclusion of population in development of this form of tourism. In the greatest number of cases, there were given the answers that rural population can be included in development of rural tourism through: production and sale of agricultural products to tourists (33 respondents), providing accommodation in private households (33 respondents), organization of attractive manifestations (32 respondents) etc.

\section{Conclusions}

The subject of the study in this paper refers to the analysis of the possibilities for rural tourism development on Goč mountain as a factor of the improvement of rural population's life quality on this mountain. Based on the analysis of the existing resources, we can conclude that Goč mountain offers potentials for rural tourism development although this form of tourism is still not present in its overall tourist offer. In this paper, there is an empirical study carried out in order to analyze the attitudes of respondents on development of rural tourism and manners for the inclusion of rural population in its development in order to obtain a better material position and life quality. Main hypothesis, from which empirical study has started, and which says: Rural tourism can contribute to the improvement of rural population's life quality on Goč mountain is confirmed having in mind that four of the set five hypotheses, based on which main one was operationalized, are confirmed by appropriate statistical methods. The implemented research has confirmed the existence of the resources for rural tourism development, as well as the fact that rural population is not sufficiently included in its development. In addition, by this study there were confirmed the manners for the improvement of rural tourism offer, as well as more intensive engagement of rural population in its development.

For a more successful development of rural tourism, it is required to set a good communication between all the crucial stakeholders of Goč mountain, particularly between local population that takes part in development of rural tourism and public and private sector. Local population can have a crucial role in the development of rural tourism of Goč mountain and it should be in many ways included directly in its development. First of all, local population can sell its products to catering facilities and tourists, they can also rent their private households to tourists, they can organize attractive manifestations such as gastronomic and/or manifestations that refer to folklore and the like. Success in development of rural tourism on Goč mountain can be achieved by joining of the local population that directly takes part in development of this tourism form for the sake of creation and promotion of tourist offer like it is done in Cluj County in Romania. 


\section{Acknowledgements}

Paper is a part of research within the project no. III 46006 - Sustainable agriculture and rural development in the function of accomplishing strategic objectives of the Republic of Serbia in the Danube region, financed by the Ministry of Education, Science and Technological Development of the Republic of Serbia. Project period: 2011-2018.

\section{Conflict of interests}

The authors declare no conflict of interest.

\section{References}

1. Accommodation on Goč mountain, Retrieved from https://www.goc.rs/smestaj/ ( November 19, 2018). [in Serbian: Smeštaj na planini Goč].

2. Barbieri, C. (2013). Assessing the sustainability of agritourism in the US: a comparison between agritourism and other farm entrepreneurial ventures, Journal of Sustainable Tourism, 21(2), 252-270.

3. Đenadić, M., Muhi, B., \& Jovanović, V.D. (2016). Rural tourism - Serbia's missed chance, Economics of Agriculture, 63(2), 515-529.

4. Garrod, B., Wornell, R., \& Youell R., (2006). Re-conceptualising rural resources as contryside capital: The case of rural tourism, Journal of Rural Studies, 22, 117-128.

5. Grossman E. (2013). Kurokawa No: Shaping the Image and Perception of Japan's Folk Traditions, Performing Arts and Rural Tourism, Global Oriental.

6. Irshad, H. (2010). Rural tourism - An overview, Government of Alberta, Agriculture and Rural Development, Retrieved from, https://www1.agric.gov. ab.ca/\$Department/deptdocs.nsf/al1/csi13476/\$FILE/Rural-Tourism.pdf ( October 12, 2018)

7. Jaszczak, A., \& Žukovskis, J. (2010). Tourism business in development of European rural areas. Management theory and studies for rural business and infrastructure development, 20(1), 35-44.

8. Košić, K., Demirović, D., Pejanović, R., Lazić, L., \& Stamenković, I. (2015). Key principles of rural tourism households development strategy - Case study of Vojvodina, Economics of Agriculture 62(4), 975-988.

9. Kostić, M., \& Petrović, M. (2013). The importance of biodiversity conservation as a factor of ecotourism development at the Goč mountain. Hotel and Tourism Management, 1(1), 56-66.

10. Lane, B. (1994). What is Rural Tourism? In: Bramwell B, Lane B, editors. Rural Tourism and Sustainable Rural Development. Clevedon: Channel View Publications.

11. Liu, C.Z. (2002). A Study on Leisure Agriculture and Rural Development. The Journal of Rural Development Perspectives, Vol. 3, 19-33. 
12. Maksimović, M., Urošević, S., \& Mihajlović, D. (2015). The Effects of the Development of Rural Tourism on Stara Planina, Ekonomika, 61(2), 83-92.

13. McGehee, N.G., \& Kim, K. (2004). Motivation for agri-tourism entrepreneurship. Journal of Travel Research, 43(2), 161-170.

14. Milićević, S., \& Đorđević, N. (2015). Potentials for the development of Goč mountain as a rural tourism destination. Ekonomija teorija i praksa, 8(4), 86-97. [in Serbian: Milićević, S., \& Đorđević, N. (2015). Potencijali za razvoj planine Goč kao destinacije ruralnog turizma].

15. Milićević, S., \& Podovac, M. (2012). Potentials for rural tourism development on Goč, $1^{\text {st }}$ Professional Conference about Rural Tourism and Sustainable Development, Kragujevac, November 23, 2012. 75-83. [in Serbian: Milićević, S., \& Podovac, M. (2012). Potencijali planine Goč za razvoj ruralnog turizma].

16. Milićević, S., Podovac, M., \& Čavlin, M. (2015). Resources for development of the Rača municipality as rural tourism destination, Economics of Agriculture, 62(3), 751-765.

17. Mitchell, M., \& Hall, D. (2005). Rural Tourism as Sustainable Business: Key Themes and Issues, in Rural Tourism and Sustainable Business, Hall D., Kirkpatrick I. and Mitchell M. (eds), Channel View Publications, 3-14.

18. Molera, L., \& Albaladejo, I. P. (2007). Profiling segments of tourists in rural areas of South-Eastern Spain, Tourism Management, 28, 757-767.

19. Municipality of Vrnjačka Banja (2018). Sustainable Tourism Development Program on the Mountain Goč, 2011-2021, revised edition.

20. Municipality of Vrnjačka Banja. (2013). Sustainable Development Strategy of the Municipality of Vrnjačka Banja. Vrnjačka Banja.

21. Njegovan, Z., Demirović, D., \& Radović, G. (2015). Managing sustainable development of rural tourism in Vojvodina, Škola biznisa, 1/2015, 68-79.[in Serbian: Njegovan, Z., Demirović, D., and Radović, G. (2015). Upravljanje održivim razvojem ruralnog turizma u Vojvodini].

22. Pallant, J. (2009). SPSS Survival Manual. Mikro knjiga, Beograd.[in Serbian: Pallant, J. (2009). SPSS: Priručnik za preživljavanje]

23. Pavlović, S., \& Đorđević, T. (2013). Forecasts of the rural tourism development in Kosjerić and Gornji Milanovac municipalities. Journal of the Geographical Institute Jovan Cvijic, SASA, 63(1), 47-64.

24. Phillip, S., Hunter, C., \& Blackstock, K. (2010). A typology for defining agritourism. Tourism Management, 31(6), 754-758.

25. Podovac, M., \& Milićević, S. (2013). Entrepreneurship in function of rural tourism development of mountain Goč, $5^{\text {th }}$ Scientific Conference RISE 2013Entrepreneurship as a Chance, Faculty of Business in Valjevo, Singidunum University, November 18-19, 2013, Valjevo, 155-161. [in Serbian: Podovac, M., and Milićević, S. (2013). Preduzetništvo u funkciji razvoja ruralnog turizma planine Goč]. 
26. Prentović R., Kurjački A., \& Cvijanović D. (2012). Hunting in Rural Areas of Bačka, Economics of Agriculture, 59(3), 385-400.

27. Saarinen, J., \& Lenao, M. (2014). Integrating tourism to rural development and planning in the developing world, Development Southern Africa, 31(3), 363-372.

28. Sharpley, R. (2002). Rural tourism and the challenge of tourism diversification: The case of Cyprus. Tourism Management, 23(3), 233-244.

29. Simić, V. (2015). Entrepreneurship in tourism on the example of good practice: Ethno villages Latkovac in Serbia. Ekonomski signali: poslovni magazin, 10(2), 57-69.

30. Statistical Office of the Republic of Serbia, 2011 Census of Population, Retrieved from http://popis2011.stat.rs/, (October 16, 2018)

31. Štetić, S. (2012). Specific Features of Rural Tourism Destinations Management, Journal of Settlements and Spatial Planning, Special Issue, vol. 1, 131-137.

32. Toader, V., Sofica, A., Petrescu, C. D., Negrusa, A. L., \& Balint, C. (2013). Best practices in developing rural tourism in Cluj County, Romania. In Proceedings of The International Conference on Tourism, Transport, and Logistics 2013, 513-517.

33. Vrnjačka Banja, Goč mountain, Retrieved from http://www.vrnjackabanja.co.rs/ srpski/sadrzaj/turizamglmeni/planinagocglmeni, (October 16, 2018). 